\title{
Risk and career choice: Evidence from Turkey
}

\author{
Asena Caner ${ }^{\mathrm{a}, *}$, Cagla Okten ${ }^{\mathrm{b}}$ \\ a Department of Economics, TOBB-Economics and Technology University, Ankara, Turkey \\ b Department of Economics, Bilkent University, Ankara, Turkey
}

\section{A R T I C L E I N F O}

\section{Article history:}

Received 15 September 2009

Received in revised form 16 April 2010

Accepted 31 May 2010

\section{JEL classification:}

012

015

I20

HO

\section{Keywords:}

Career choice

Labor income risk

Income

Education

Turkey

\begin{abstract}
A B S T R A C T
In this paper, we examine the college major choice decision in a risk and return framework using university entrance exam data from Turkey. Specifically we focus on the choice between majors with low income risk such as education and health and others with riskier income streams. We use a unique dataset that allows us to control for the choice set of students and parental attitudes towards risk. Our results show that father's income, selfemployment status and social security status are important factors influencing an individual in choosing a riskier career such as business over a less risky one such as education or health.
\end{abstract}

(c) 2010 Elsevier Ltd. All rights reserved.

\section{Introduction}

It is well documented that college graduates earn significantly more than high school graduates. Less well known are the differences in the college premium across majors and how these differences affect an individual's decision on which type of human capital to obtain in college. Investment in college education allows a person to earn a stream of labor income depending on the properties of the major he has chosen. In this way, investment in education is similar to a financial investment and is likely to be affected by return and risk concerns of the investor. In this paper, we examine the college major choice decision in a risk and

\footnotetext{
* Corresponding author at: Department of Economics, TOBBEconomics and Technology University, Sogutozu Cad. No. 43, Ankara, Turkey. Tel.: +90 312292 4111; fax: +90 3122924104.

E-mail address: acaner@etu.edu.tr (A. Caner).
}

return framework using a nationally representative survey of university entrance exam applicants from Turkey.

Arcidiacono (2004) points out that large earnings and ability differences exist across majors, based on the US data of students' college major choices in 1972 (their first year in college) and 1974 and their reported earnings in 1986. He finds that large earnings differences exist even after controlling for self-selection according to ability. Saks and Shore (2005) argue that there may be major specific idiosyncratic risk if agents do not know their ability before entering a career and if differences in ability cause dispersion in wages.

In many developing countries, there is also significant macro-level unemployment risk due to periodic economic crises in addition to labor income risk due to individual differences in ability. Yet, those employed in the public sector are subject to a much smaller unemployment risk than those employed in the private sector. For example, in Turkey, graduates of certain majors such as education 
and health are largely employed by the public sector where employees are rarely fired or laid off(Ministry of Education, Ministry of Health ${ }^{1}$ (2008)). Economic theory tells us that agents would require a premium to enter into careers that they perceive as riskier. However, richer individuals should demand smaller risk premiums and consequently be more willing to choose riskier careers.

Saks and Shore (2005) analyze the major choice decision in a risk and return framework using US data and find that wealthier individuals are more likely to choose riskier majors such as business. Our paper contributes to this small literature by advancing the analysis in several dimensions: first, we consider differences in macro-level unemployment risk in addition to wage income risk due to individual differences in ability.

Second we allow for parental influences when measuring the effect of parental income on major choice. We use father's self-employment and social security status variables to measure the effects of parental preferences. The Turkish social security system offers different programs to public and private sector employees. This characteristic enables us to identify fathers who have chosen a public sector career. Third, we fully control for the university/major choice set available to the student as the university entrance exam (OSS) score is the only determinant of university/major placement in Turkey. Researchers who work with US data use SAT scores, which are informative of students' choice sets but do not completely determine the available choices, since other factors such as extracurricular activities, essays and even demographic characteristics such as race and income also play a role.

Finally, ours is the first econometric study on a developing country that examines the influence of parental income on college major choice. The impact of income and risk on career choice has important policy implications for developing countries that have significant income inequalities. Poor students may be systematically more likely to avoid risky human capital investments, even if these investments entail high expected personal returns. This dynamic may further perpetuate the existing income inequality within a society. Furthermore, to the extent that high personal returns also imply high social returns, it may be efficient for governments to provide larger subsidies for these investments to poor students.

Our main finding is that parental income, father's selfemployment status and social security status are important determinants of choosing a riskier major such as business over a less risky one such as education, controlling for the OSS score and other socio-economic characteristics. Controlling for university preferences in a university fixed effects specification, we find that a $100 \%$ increase in parental income increases the relative probability of majoring in business over education by $64 \%$. A change in father's status to self-employment increases the relative probability of majoring in business over education by $49 \%$. A student whose father belongs to the public sector social security

\footnotetext{
1 Relevant statistics are acquired from these ministries via formal requests or from their websites when possible. More information on this is provided in Section 5 .
}

system is $47 \%$ less likely to choose business major over education. Hence we find strong evidence that income is a very important factor in increasing a student's probability of choosing a riskier major over a less risky one controlling for father's job preferences.

Isolating the exact mechanisms through which parental income may affect choice of riskier majors such as business is challenging. In the presence of unobserved heterogeneity, parental income might proxy for unobserved parental resources such as social and business networks or parental risk and job preferences. We include father's self-employment and social security status in order to control for these unobserved characteristics. In addition, we control for the population of the town that the student comes from to measure for the size of these important networks. Despite our efforts to control for unobserved heterogeneity, we should add a caveat that there might be other channels through which parental income might influence the choice of a riskier major. Nevertheless, our finding that high return high-risk majors are chosen by those with rich and self-employed parents has important implications for intergenerational income mobility and transmission of income risk. In other words, we provide strong evidence for the intergenerational transmission of intra-generational mobility and this result in and of itself is worthy of attention.

The plan for our paper is as follows: in the next section we summarize the related literature. In Section 3, we describe the university entrance exam system in Turkey. Section 4 builds the theoretical framework of the paper. In Section 5, we explain how we determine labor income risk in Turkey. After describing the data in Section 6 and the econometric model in Section 7, we discuss the results of our study in Section 8. Section 9 concludes our paper.

\section{Related literature}

There is a large literature on estimating the monetary returns to college education. The standard approach to measure these returns is a Mincer equation which regresses income on educational attainment as well as other demographic characteristics. Prominent examples are Ashenfelter and Krueger (1994) and Angrist and Krueger (1991). In Turkey, returns to education are found to be the highest at the university level in 1987 (Tansel, 1994). In 1989, returns to university education of wageearner men are comparable to those of self-employed men (Tansel, 2001). In 1994, returns to university education are higher in the private sector than in the public sector (Tansel, 2005).

A related body of literature examines the problem of choosing the optimum quantity of educational investment. Becker (1964) observes that since human capital is both risky and illiquid it should demand a premium over safer assets. Levhari and Weiss (1974), Williams (1979) and Judd (2000) model the decision about what quantity of education to receive when investment in education is risky.

There are relatively few papers that examine the link between type of major and returns to major choice. Boskin (1974) finds that an occupation with higher lifetime earnings and lower training costs is more likely to be chosen. 
Berger (1988) finds predicted future earnings influence the college major choice of young men. Neither of these papers analyzes the differential impact of initial (family) income on different careers.

Saks and Shore (2005) examine how the financial risk associated with different careers influences career choice using the US data. In their model, individuals demand a premium to enter careers with more idiosyncratic risk. However, if agents have DARA (decreasing absolute risk aversion) preferences, the required size of the premium falls with family wealth. Hence, controlling for ability and preferences, wealthier individuals should demand smaller risk premiums and be more eager to choose riskier careers. They analyze students who have already chosen their majors and use SAT scores to control for students' choice set. They control for neither parents' self-employment status nor sector of employment.

In the major choice decision, parental characteristics may have an important role along with risk and return characteristics of careers that are related to the chosen majors. There is strong evidence for intergenerational transmission of occupational status (Kerckhoff, Campbell, \& WinfieldLaird, 1985; Nguyen \& Haile, 2003). Carmichael (2000) finds that the occupational attainment of sons depends significantly on the socio-economic status of their fathers.

Liu, Chou, and Liu (2006) and Tansel (2002) show that parents' income and education levels have important positive effects on children's educational achievements. There is evidence that parents' risk attitudes are correlated to those of their children (Dohmen, Falk, Huffman, \& Sunde, 2006). The transmission of risk attitudes could work through various channels; genetics, child learning by imitation, or deliberate efforts by parents to shape the preferences and beliefs of their children.

Also related to our study is the literature on the effect of parental characteristics on entrepreneurship. It is well known that the children of the self-employed display a greater propensity to become entrepreneurs. One explanation of this phenomenon is that starting up a business requires capital. Successful entrepreneurs help ease the financial constraints of their children by transferring funds to them. Evans and Leighton (1989) find that assets have an important role in men's transition to self-employment. Another explanation is that parents transmit to the children their work experience, reputation and other managerial human capital. Dunn and Holtz-Eakin (2000) find that the parents' strongest influence comes from the transmission of their own self-employment experience and secrets to business success. These findings suggest that the occupational status of the parents may have an influence on the children's career choice and thus should be included in the analysis.

\section{The setting: the university entrance exam in Turkey}

Students who wish to receive university education are required to take a nationwide test called the OSS (can be translated as "Student Selection Exam"). The OSS is a highly competitive national event. It is given once a year and more than 1 million students participate each year. In 2003, "of
Table 1a

Programs compatible with the TM field.

\begin{tabular}{ll}
\hline Major & Programs \\
\hline 1. Education & $\begin{array}{l}\text { Kindergarten education, mathematics } \\
\text { education, philosophy education, education of } \\
\text { the visually impaired } \\
\text { Banking and finance, tourism management, } \\
\text { insurance, international finance, international } \\
\text { trade, logistics, accounting } \\
\text { Economics, political science, public finance, } \\
\text { international relations, public administration, }\end{array}$ \\
3. Econ-Pol-IR & $\begin{array}{l}\text { European Union relations } \\
\text { Anthropology, philosophy, sociology, } \\
\text { psychology } \\
\text { 4. Social Sciences } \\
\text { Turkish language and literature }\end{array}$ \\
6. Law &
\end{tabular}

Source: OSYM (2002).

Table 1b

Programs compatible with the Science field.

\begin{tabular}{|c|c|}
\hline Major & Programs \\
\hline 1. Education & $\begin{array}{l}\text { Kindergarten education, mathematics } \\
\text { education, philosophy education, education of } \\
\text { the visually impaired, computer education }\end{array}$ \\
\hline 2. Business & Business \\
\hline 3. Econ-Pol-IR & Economics, econometrics \\
\hline 4. Engineering & All engineering programs \\
\hline 5. Science & $\begin{array}{l}\text { Physics, chemistry, biology, genetics, } \\
\text { astronomy }\end{array}$ \\
\hline 6. Health & $\begin{array}{l}\text { Medicine, dentistry, nursing, veterinary, } \\
\text { midwifery }\end{array}$ \\
\hline
\end{tabular}

Source: OSYM (2002).

those taking the examination only $21.5 \%$ was placed in a 2 or 4 year university program. About two-thirds of those taking the examination were repeat takers while one-third were fresh high school graduates sitting in the examination for the first time" (Tansel \& Bircan, 2005, p. 2).

The exam is composed of different sections. Students decide which sections to answer based on their major choices. In 2002, the year that our data was collected, the OSS had two main sections (verbal and quantitative) and a foreign language section. The raw OSS score was a weighted average of the scores on these sections.

The raw OSS scores were further adjusted for high school performance. In Turkey, high school students choose fields of study. In the 2002 data provided by the Student Selection and Placement Center (OSYM), there were four fields; Science, Turkish-Math (TM), Social Sciences and Foreign Languages. ${ }^{2}$ As part of a policy to encourage students to choose programs that are compatible with their high school fields, a bigger adjustment factor was used if the chosen programs were compatible with the high school field.

We report in Tables $1 \mathrm{a}$ and $1 \mathrm{~b}$ lists of programs that are compatible with students who graduate from high school with the TM and the Science fields, respectively. We focus on these fields since the majors we want to analyze such as business and health are more likely to be chosen by students who come from these fields. We match these

\footnotetext{
2 To be precise, there were two other fields, namely arts and theology, but we do not have any data on the students in these fields.
} 
programs to majors according to their risk and return characteristics, based on the groupings that we observe in the literature and the characteristics of the Turkish labor market described in Section 5.

Students who scored above a certain threshold were asked to submit their choice lists. Each candidate could include up to 24 choices (program-university pairs) in the list, ranked from the most preferred to the least preferred. The candidate with the highest OSS score was admitted to the first program in his choice list. As the quotas of the most popular programs were filled, candidates with lower OSS scores were assigned to their less preferred programs, or to no programs at all if the quotas of all the programs in their choice lists had already been filled.

\section{Theoretical framework}

\subsection{Model}

In this section we build on the theoretical framework of Saks and Shore (2005) who model individual differences in ability as the cause of variability in labor income streams and argue that certain majors such as business have more variable income streams than others. Our focus here is on differences in variability of labor income streams across majors that lead to private sector versus public sector employment. In addition to individual differences in ability that lead to more variable incomes in the private sector, we model macro-level unemployment risk as an important factor that adds to this variation.

We assume that the utility functions of parents and offsprings are functions of the financial resources that the individual has access to and job characteristics. In particular, let the utility of individual $i$ from choosing career $c$ be denoted by:

$U_{c}^{i}=U\left(W_{o}+Y_{c}^{i}, \gamma_{c}^{i}\right), \quad i=\left\{\begin{array}{cc}P, & \text { if parent } \\ 0, & \text { if child }\end{array}\right.$,

where $W_{o}$ is initial wealth which is the bequest from parents and $Y_{c}^{i}$ is labor income of individual $i$ from career $c$. The $\gamma$ parameter represents non-pecuniary characteristics of a career. These characteristics can be number of working hours, flexibility of hours, working conditions, social status of the job and the public versus private nature of the job. We will assume that the preferences for non-pecuniary characteristics of parent and offspring are correlated.

We assume that agents are risk-averse when they make their major choices. Labor income $Y_{C}$ depends on an agent's career choice:

$Y_{c}^{i}= \begin{cases}w_{c}^{\text {pub }}, & \text { if public } \\ w_{c}^{p r i}, & \text { if private }\end{cases}$

Labor incomes earned in public and private sector jobs can be expressed as:

$w_{c}^{p u b}=\bar{w}_{c}^{p u b}$,

$w_{c}^{p r i}=\bar{w}_{c}^{p r i}+\alpha^{i}+\eta_{c}$,

where $\alpha^{i}$ represents variation in earnings in private sector due to differences in individual ability, drawn from a distribution with zero mean and variance $\sigma_{\alpha}^{2}$. The underlying assumption is that ability can have an effect on earnings in the private sector while it has no effect in the public sector. While this may be an oversimplification, it is true that earnings in the public sector do not vary much and depend almost entirely on seniority. A very talented teacher and an untalented one of equal rank are likely to get the same salary. Individuals do not have perfect information on their ability when they choose a career. Important for our analysis, we assume that $\alpha^{P}$ and $\alpha^{0}$ are correlated; i.e. the abilities of the parent and the offspring are correlated.

In Eq. (3b), $\eta_{c}$ represents variation in earnings in private sector career $c$ due to the unknown nature of employment (for instance, due to risks originating from changes in supply and demand conditions). We refer to this as macroeconomic unemployment risk. Since public sector employees are almost never laid off, they do not bear this risk. We assume that $\eta_{\mathrm{c}}$ is drawn from a distribution with mean zero and variance $\sigma_{\eta c}^{2}$.

We consider career $c$ to be safer than career $c^{\prime}$ if $Y_{c}$ second order stochastically dominates $Y_{c^{\prime}}{ }^{3}$ All riskaverse expected utility maximizers prefer a second order stochastically dominant career to a dominated one. Therefore, expected labor income in the private sector, $\bar{w}_{c}^{p r i}$, should be high enough to compensate for ability risk and career-specific labor income risk, otherwise no riskaverse agent would ever prefer the private sector. If in addition to risk aversion we assume that agents have decreasing absolute risk aversion $\left(D_{A R A}{ }^{4}\right.$ ), agents become less concerned about specific risks as they get richer. $^{5}$

\subsection{Determinants of career choice}

\subsubsection{Risk preferences}

An important determinant of career choice is the risk preference of an individual. One reason why individuals might differ in their degrees of risk aversion is differences in their access to financial resources. As we mentioned before, richer agents are more eager than poorer agents to undertake risky careers, ceteris paribus. In our empirical framework, we will use family income as the indicator of wealth bequest that the individual receives from his family. We also control for the number of siblings that the student has and the number of hours of tutoring that the student received before taking the exam, since these variables also indicate the extent to which the student is supported by his family financially.

\footnotetext{
${ }^{3}$ If career c yields unambiguously higher income than career $c^{\prime}$ then we say that $Y_{c}$ first order stochastically dominates $Y_{C^{\prime}}$. If career c second order stochastically dominates career $c^{\prime} \int_{0}^{y} F\left(Y_{c}\right) d Y_{c} \leq \int_{0}^{y} F\left(Y_{c^{\prime}}\right) d Y_{c^{\prime}}$ for all income levels y, where $F($.$) indicates the cumulative distribution func-$ tion. By definition, first order stochastic dominance implies second order stochastic dominance, but not vice versa.

4 DARA preferences are such that the coefficient of absolute risk aversion $r(Y)=-\frac{U^{\prime \prime}(Y)}{U^{\prime}(Y)}$ is decreasing. An example of such a utility function is $U=\ln (Y)$. We should also note that both experimental and empirical evidence seem to support DARA preferences. See for example Levy (1994).

5 Saks and Shore (2005) provide a proof of this statement.
} 


\subsubsection{Job preferences}

Another important determinant of career choice is an individual's job preferences. Some individuals seek independence and enjoy being self-employed, while others enjoy well-specified working hours. Preferences for working conditions or the social status associated with the job can also vary across individuals. We assume that job preferences might be transferred across generations through the inheritance of genes, information and social networks.

In our empirical framework, we use father's selfemployment status and father's social security status variables as indicators of parents' job preferences which might be transferred to their offspring. We therefore expect students whose fathers are self-employed to choose a major such as business. We expect those whose fathers belong to the public sector social security system to choose majors that lead to employment in the public sector.

It is plausible that women have different job preferences than men, due to their responsibilities at home. For example, women may prefer teaching due to more flexible hours. Women and men might also differ in their attitudes towards risk. ${ }^{6}$ Therefore, in our empirical model, we control for the gender of the student.

The population of the area that a student comes from might also affect his major choice. Since private sector jobs are scarce in small towns, we expect the business networks of those that come from small towns to be limited. Even if these students consider living in big cities after graduation, they may lack the necessary social networks that will help them find jobs in the private sector. As a result students from small towns may be more likely to choose majors such as education and health. To control for this effect, we use in our empirical specification the population of the area in which the student went to high school.

\subsubsection{Ability}

Ability can play a role in sorting individuals into different careers. OSS score is a measure of scholastic aptitude and we hypothesize that it is likely to be correlated with ability that determines future earnings. Within the OSS system, students know their scores before they make their choices, and we expect students with higher scores to choose riskier careers that yield higher expected income.

In Turkey, students often take the OSS multiple times before they can manage to get a score that makes placement possible. Hence we control for the number of times that the individual has taken the OSS as an indicator of experience with the exam and as another indicator of ability. While the average repeat taker might have lower ability than the average first-timer, he has more experience with the exam and possibly a longer time to prepare for it. Hence the expected sign on this variable is theoretically ambiguous.

As stated before, individuals do not have perfect information on their ability. They learn about it over time, after they have chosen and perhaps started practicing their

\footnotetext{
6 There is evidence that women exhibit greater risk aversion in their financial decisions than men. See for example, Jianakoplos and Bernasek (1998).
}

careers. In this model, father's education may be an indicator of the offspring's true ability as abilities are correlated across generations. Thus, we use father's education level to control for the possible transmission of ability from parent to offspring.

\subsubsection{Credit constraints}

Students with credit constraints may choose majors with lower education costs or with better fellowship/scholarship opportunities. In Turkey, the Ministry of Education offers scholarships to increase the supply of teachers. This program supports a number of students (the quota may change yearly but it was between 1000 and 2000 in years 2000-2004) who specify an education program within their top five choices and who are admitted to one of these programs, by providing them with a scholarship during their studies with a condition to work in the public sector after graduation. This incentive may have influenced the major choices of credit constrained students. We test for this possibility as part of our robustness checks.

\section{Estimating labor income risk}

In Turkey, there is macro-level unemployment risk due to periodic economic crises as well as labor income risk due to individual differences in ability. Certain majors such as education and health are perceived to be safer than others in terms of macro-level unemployment risk.

According to our estimates based on a $5 \%$ representative sample of Turkish 2000 Census (Turkish Statistical Institution (TUIK), 2000) unemployment rates of teachers and physicians are much lower than those of other occupations. TUIK asks each respondent about his employment status and current occupation if the respondent is in the labor force. Table 2 shows the mean and the standard deviation of the unemployment rates ${ }^{7}$ of various occupations as well as the number of observations in each category. The figures support our thesis that careers in teaching and medical professions are more secure than others.

While only $4.71 \%$ of teachers and $6.60 \%$ of medical professionals are reported as unemployed, about $8 \%$ of accountants and managers (retail and wholesale industries), $13.96 \%$ of economists, $13.98 \%$ of physicists and chemists and $11.49 \%$ of engineers are unemployed. We have conducted tests to examine whether the average unemployment rates of teachers are different from those of accountants, managers or economists and found the differences in means to be statistically different at $1 \%$ significance level. We have also found that the average unemployment rate of medical professionals is statistically different from that of engineers or physicists and chemists again at $1 \%$ significance level. These findings provide strong evidence on the relatively low unemployment rates of careers in teaching and medical professions. We should note that these rates precede the 2001 economic crisis in Turkey where there were massive layoffs from financial and manufacturing sectors that are likely to increase differences between

\footnotetext{
7 For each occupation, we compute the unemployment rate by dividing the number of unemployed by the size of the labor force in that occupation.
} 
Table 2

Occupation specific unemployment rates.

\begin{tabular}{llr}
\hline & Mean & Standard deviation \\
\hline Teachers & 0.0471 & 0.2118 \\
Lawyers and other legal professionals & 0.0631 & 0.2432 \\
Medical professionals & 0.0660 & 0.2483 \\
Accountants & 0.0789 & 0.2696 \\
Managers (retail, wholesale) & 0.0814 & 0.2739 \\
Engineers, architects & 0.1149 & 0.3189 \\
Statisticians, mathematicians & 0.1226 & 0.3282 \\
Economists & 0.1396 & 0.3466 \\
Physicists, chemists & 0.1398 & 0.3469 \\
\hline
\end{tabular}

Source: Authors' calculations from 5\% sample of Turkish 2000 Census (TUIK, 2000).

unemployment rates of teachers (medical professionals) and business (engineering) majors.

Hence we argue that, if education and health degrees are more likely to shelter an individual from unemployment risk then we would expect agents with higher risk aversion to choose these majors.

Studies based on survey data point out that job security is an important factor in choosing careers in teaching and medicine. Ovet (2006) surveys students enrolled in the Faculty of Education at Eskisehir Osmangazi University and finds that the top two reasons for choosing the education major are non-pecuniary returns such as being fond of children and search for job and retirement security. ${ }^{8}$

Based on a survey of medical school students, Alper and Ozdemir (2004) report that the "employment guarantee factor" is the second most important reason for choosing medical school after the "willingness to help others" factor which is ranked the first.

The public sector is the largest employer of teachers and health personnel in Turkey where public sector employees are rarely fired or laid off. Currently there are 622,864 teachers employed in the public education system and only 34,321 teachers employed by private teaching institutions (Ministry of Education, February 2008, http://personel.meb.gov.tr). According to the latest statistics released by the Ministry of Health, $81 \%$ of doctors, $85 \%$ of nurses and $93 \%$ of midwives are employed by the public sector (Ministry of Health, 2008).

Graduates with education or health degrees have a higher chance of being employed in the public sector, compared to graduates of other majors. About $48 \%$ of the $1,632,482$ civil servants employed by the central government (the bulk of public sector employees) are employed in the education (35\%) and the health sector (13\%) (Guler, 2003). Out of the 189,491 students who graduated from Turkish universities in the 2002-2003 academic year, $19.65 \%$ had an education degree and only $7.43 \%$ had a health related degree (authors' calculations based on the statistics provided by the Turkish Council of Higher Education (YOK)). These numbers allow us to draw a distinction: while only $27.08 \%$ of graduates have education or health degrees, teachers and health personnel constitute $48 \%$ of civil servants. These two fields are clearly overrepresented in public sector employment.

\footnotetext{
8 The other two factors were not having a high enough score to major in another field and having been influenced by a teacher acquaintance.
}

The students in our dataset made their major choice in 2002. To estimate the chances of an education faculty graduate to be hired as a public school teacher, we compare the number of first-time hires to the number of graduates in (or close to) $2002 .{ }^{9}$ Strikingly, in the years 2000-2002, the number of total hires exceeded the number of graduates of Education Faculties by $14-48 \%{ }^{10}$ In these years, it appears that teachers had a very good chance of finding a public sector job. During the years 2003-2008, the ratio of the number of first-time hires to the number of graduates varies from 48 to $77 \%$ implying that an Education Faculty graduate still had a good chance of being employed in the public sector. ${ }^{11}$

While the wages of public school teachers vary according to rank, seniority, type of school, the variance is not large. The monthly (net) wages are between 800 and 1600 US dollars for teachers of all ranks and types (information provided by the Ministry of Education, Personnel Department, upon formal request). For a starting teacher, it is not even realistic to talk about a wage variance in the public school sector. $^{12}$

The Ministry of Health provides data on the average net wages of health personnel in the public sector by profession (Ministry of Health, 2005). According to these data, average monthly net wages in 2004 were 700 for nurses and

\footnotetext{
9 The numbers of first-time hires (i.e. those who never worked before as a public school teacher) were provided by the Ministry of Education, Personnel Department upon our formal request. The data on the number of graduates come from the Higher Education Statistics on the Student Selection and Placement Center (OSYM) website (http://www.osym.gov.tr/BelgeGoster.aspx?F6E10F8892433CFFAAF6AA 849816B2EF8F59EC4393613791). Graduates of earlier years can of course apply for a public school teaching job.

10 For the years 2000-2002, we do not have data on first-time hires since we have been provided only with the total number of teacher hires, which includes location transfers, those who quit teaching some time ago and returned and so on. According to data from years 2003-2009, first-time hires constituted $80-95 \%$ of total hires. Therefore, we can say that the bulk of total hires is first-time hires. As before, the data for the number of graduates come from OSYM, years 2001, 2002, 2003.

11 In recent years, getting a public school teaching job has become increasingly more competitive partly due to a combination of an increase in the supply of education faculty graduates and a decrease in hires and partly due to a shift in public policy that allowed graduates of other majors become public school teachers after completing a Master's program in pedagogy.

12 Actually this is true for all public sector employees as they are offered the same wages at the entry level (i.e. no variation due to ability) and modest rates of wage raises by rank.
} 
Table 3a

Descriptive statistics of the survey data on Bilkent University graduates.

\begin{tabular}{|c|c|c|c|}
\hline & & Frequency & Percent of the sample \\
\hline Sex & $\begin{array}{l}\text { Male } \\
\text { Female }\end{array}$ & $\begin{array}{l}375 \\
307\end{array}$ & $\begin{array}{l}55.0 \\
45.0\end{array}$ \\
\hline Age group & $\begin{array}{l}20-25 \\
26-30 \\
31-35 \\
36-40 \\
41-45\end{array}$ & $\begin{array}{r}393 \\
183 \\
79 \\
25 \\
2\end{array}$ & $\begin{array}{l}57.6 \\
26.8 \\
11.6 \\
3.7 \\
0.3\end{array}$ \\
\hline Business & $\begin{array}{l}\text { Management } \\
\text { Accounting information systems }\end{array}$ & $\begin{array}{r}152 \\
13\end{array}$ & 24.2 \\
\hline Econ-Pol-IR & $\begin{array}{l}\text { Economics } \\
\text { Political science } \\
\text { International relations }\end{array}$ & $\begin{array}{r}135 \\
64 \\
92\end{array}$ & 42.7 \\
\hline Engineering & $\begin{array}{l}\text { Electrical and electronics engineering } \\
\text { Industrial engineering } \\
\text { Computer engineering }\end{array}$ & $\begin{array}{l}50 \\
95 \\
81\end{array}$ & 33.1 \\
\hline Number of observations & & & 682 \\
\hline
\end{tabular}

Source: Authors' calculations based on the survey of Bilkent University graduates.

midwives, 900 for pharmacists, 1100 for medical doctors, ${ }^{13}$ all expressed in US dollars. There is not much variation by rank. An important source of earnings variation is extra payments made by revolving funds at some hospitals that can amount to $400-550 \$$ for nurses and $1000-2500 \$$ for medical doctors.

We have established that job security is an important characteristic of careers in education and health. Next, we look at the wage differences across other majors to determine which of these majors have higher income risk. Unfortunately, there are no major specific wage data available for Turkey. Hence we conducted a survey among the graduates of Bilkent University. ${ }^{14}$ Within an occupation, cross-sectional differences in wages is one measure of labor income risk, however it is an imperfect measure since the cross-sectional dispersion in wages cannot differentiate unobserved heterogeneity from risk. If people know their ability before entering a career, then the cross-sectional dispersion of wages will overestimate the degree of risk.

In the survey, we asked questions on the sex, age, department of graduation, years of experience in current job, years of experience in previous jobs, father's education level and monthly net compensation (i.e. net income plus any subsidies) of salaried and wage earning respondents. ${ }^{15}$

\footnotetext{
${ }^{13}$ We prefer to exclude medical specialists from the earnings comparison as being a specialist requires extra training after a university degree. In Turkey, medical school is an undergraduate school whose graduates can either work as medical doctors or study an extra 3-5 years and become specialists.

14 Bilkent University is a prestigious private university in Turkey. It enrolls about 12,000 students and has strong alumni/ae contacts, which enabled us to conduct our survey. However, it does not offer any education or health programs, therefore we cannot obtain any information on the riskiness of these fields based on these data.

${ }^{15}$ The respondents filled out the surveys without revealing their identity. Hence we do not have any reason to expect that response rate will depend on income. We requested the respondents to choose from a set of income brackets.
}

We use the survey data that we collected to examine the compensation differences among salaried or wage workers who graduated from departments that coincide with the categories in our analysis. As shown in Table 3a, we have 682 observations. The breakdown of graduates according to sex, age and majors is shown in the table. The advantages of our survey data are that the respondents are mostly young, meaning that they are less likely to know their abilities, and that we can control for observable measures of ability.

Using these data, we compute and report in Table $3 \mathrm{~b}$, the unconditional and conditional means and standard deviations of monthly compensation by college major along with the minimum and maximum values. The "unconditional" statistics are directly observed in the cross-section. To remove at least some part of the dispersion in crosssectional wages that is due to unobserved heterogeneity rather than risk, we control for individual and parental characteristics via an OLS regression. The descriptive statistics of the residuals from this regression are what we report as "conditional" in the table.

Based on the statistics reported in Table 3b, we can compare business majors to Econ-Pol-IR majors. Given that the incomes of business majors are higher in both mean and variance, and mean income is low relative to standard deviation, we conjecture that business careers can be regarded as riskier careers. More important to our study, business, Econ-Pol-IR and engineering careers entail higher risk compared to education and health. ${ }^{16}$ Although we do not have the data to perform a similar analysis, we can make a judgment based on what we know about careers in health and education. The net monthly wages of teachers are between

\footnotetext{
${ }^{16}$ We should note that the cross-sectional differences between means of income across individuals may also reflect differences in jobs themselves such as the hours and working conditions in addition to a compensating differential for the unemployment risk. Hence Table $3 \mathrm{~b}$ provides suggestive but not conclusive evidence on ranking majors according to income risk.
} 
Table 3b

Descriptive statistics of monthly compensation by college major (in US dollars).

\begin{tabular}{|c|c|c|c|c|c|c|c|c|c|}
\hline & \multicolumn{4}{|c|}{ Unconditional } & \multicolumn{4}{|c|}{ Conditional } & \multirow[t]{2}{*}{$N$} \\
\hline & Min & Max & Mean & Standard deviation & Min & Max & Mean & Standard deviation & \\
\hline Business & 623 & 8480 & 2670 & 1889 & -3390 & 5068 & 69 & 1389 & 165 \\
\hline Econ-Pol-IR & 623 & 8480 & 2071 & 1298 & -3915 & 6848 & -285 & 1236 & 291 \\
\hline Engineering & 1023 & 8480 & 3169 & 1962 & -4302 & 5931 & 316 & 1427 & 226 \\
\hline
\end{tabular}

Source: Authors' calculations based on the survey of Bilkent University graduates.

Note: In the "conditional" part of the table we report the descriptive statistics of residuals from an OLS regression of monthly compensation on sex (1: male, 0 : female), years of experience in previous jobs, years of experience in the current job, age, age squared, seven dummy variables for father's education (the omitted dummy is no education). We report the full regression results in the Appendix Table A1. The number - 285 in the conditional mean column means that those who are "Econ-Pol-IR" graduates earn on average $285 \$$ less than the average (mean) earner in the sample, controlling for the factors listed above and in Table A1.

800 and 1600 US dollars as reported earlier, while the income range for business majors is much wider. Furthermore, the average income of a business major in our data is higher than that of teacher. Given all these observations, we conjecture that a business career has higher income risk and a higher expected return than an education career.

It is possible to make a similar comparison of health to engineering based on the statistics in Table $3 \mathrm{~b}$. The expected income for an engineer is higher and the income range for engineers is much wider compared to health personnel. As reported earlier, average monthly net earnings of health personnel are 1200 for nurses and midwives and 2500 for medical doctors, both expressed in US dollars.

\section{The data}

The 2002 data provided by the OSYM of Turkey contains one random sample from each of the four high school fields; Science, Turkish-Math (TM), Social Sciences and Foreign Languages. Each sample contains data on about 40,000 students. Since students who choose business programs are mostly from the TM field, the TM dataset is very suitable for estimating the relative risk ratio of choosing the business major over the education major. The Science dataset contains students who are mostly interested in engineering and health; it is therefore suitable for examining the choice between health and other fields such as engineering and natural sciences.

For each student, we have data on his/her OSS scores, high school performance measure, student's choice list which is a ranking of program-university pairs. Our dataset also includes information on family and individual characteristics such as the gender of the student, the number of siblings, education of the parents, employment and social security status of the parents, family income, whether and for how long the student received private tutoring to prepare for the exam, the number of times that the student has taken the exam and population of the area that student attended high school. The data on the socio-economic background of the students were collected via a survey of the students registering to take the OSS.

We merged the survey data with the list of programs in universities to which placement is made via the OSS system. With this merge, we are able to identify all programs that a particular student chooses. Since we are interested in major choice, we restricted the data to the students who specified at least one program in their choice lists. Hence our sample size drops to about 11,000 with this restriction. Further, we exclude students who listed Open University or evening programs as their first choice since these students might already have jobs and careers. This restricts the TM data to about 6500 observations and the Science data to about 9000 observations.

In 2002, there were 76 universities (including both private and public) in Turkey, with more than a total of 3000 departments offering about a hundred different 4-year degree programs. Since it is not feasible to analyze the choice decision among such a large number of programs, we group the relevant programs into majors as shown in Tables $1 \mathrm{a}$ and $1 \mathrm{~b}$.

The descriptive statistics of our samples are reported in Tables $4 \mathrm{a}$ and $4 \mathrm{~b}$. A glance at these tables shows us that family income is the highest for students who chose business major and the lowest for education major. Father's self-employment rate is the highest for those who chose business. Father's private social security holding is most common among those who chose business, Econ-Pol-IR, law and engineering majors. Father's education is higher for those who chose business than those who preferred education major. A higher percentage of those who chose business are male, relative to education. Those who chose education come from larger families, as indicated by the number of siblings. Furthermore, population and tutoring hours are the lowest for those who chose education. In sum, the students who chose education come from smaller residential areas; they have larger families and lower family income, when compared to the students who chose a riskier major such as business.

\section{Empirical framework}

We use a multinomial logit model to examine the impact of income and other variables on college major choice. We take a student's top choice of an undergraduate major as an indication of his career choice. In the multinomial logit framework, the utility that student $i$ receives from choosing major $c$ when faced with $C$ choices, is a random function of his characteristics; $U_{c}^{i}=\beta_{c}^{\prime} x_{i}+\varepsilon_{i c}$. If a 
Table 4a

Descriptive statistics of the OSS data (Turkish-Math field).

\begin{tabular}{|c|c|c|c|c|c|c|c|c|c|c|c|}
\hline Major choice & Income & $\begin{array}{l}\text { Father } \\
\text { self-employed }\end{array}$ & $\begin{array}{l}\text { Father } \\
\text { public ss }\end{array}$ & $\begin{array}{l}\text { Father } \\
\text { private ss }\end{array}$ & $\begin{array}{l}\text { Father's } \\
\text { education }\end{array}$ & Male & $\begin{array}{l}\text { Number of } \\
\text { siblings }\end{array}$ & $\begin{array}{l}\text { Tutoring } \\
\text { hours }\end{array}$ & $\begin{array}{l}\text { Times } \\
\text { exam taken }\end{array}$ & OSS score & Population \\
\hline Education & 341.58 & 0.30 & 0.28 & 0.84 & 4.15 & 0.42 & 3.23 & 235.84 & 1.97 & 130.95 & 540,161 \\
\hline \multirow{3}{*}{$n=3284$} & 4.49 & 0.01 & 0.01 & 0.01 & 0.03 & 0.01 & 0.02 & 4.95 & 0.02 & 0.13 & 10,881 \\
\hline & 125 & 0 & 0 & 0 & 1 & 0 & 1 & 0 & 1 & 100.612 & 2,500 \\
\hline & 2500 & 1 & 1 & 1 & 9 & 1 & 5 & 1500 & 5 & 159.456 & $1,500,000$ \\
\hline \multirow{4}{*}{$\begin{array}{l}\text { Business } \\
n=608\end{array}$} & 708.26 & 0.43 & 0.23 & 0.93 & 5.06 & 0.67 & 2.52 & 376.48 & 1.86 & 133.81 & $1,001,813$ \\
\hline & 25.35 & 0.02 & 0.02 & 0.01 & 0.07 & 0.02 & 0.04 & 14.62 & 0.04 & 0.43 & 25,943 \\
\hline & 125 & 0 & 0 & 0 & 1 & 0 & 1 & 0 & 1 & 107.274 & 2,500 \\
\hline & 2500 & 1 & 1 & 1 & 9 & 1 & 5 & 1500 & 5 & 165.106 & $1,500,000$ \\
\hline \multirow{4}{*}{$\begin{array}{l}\text { Econ-Pol-IR } \\
n=868\end{array}$} & 611.03 & 0.31 & 0.29 & 0.90 & 4.93 & 0.63 & 2.67 & 377.88 & 1.86 & 134.96 & 984,986 \\
\hline & 17.75 & 0.02 & 0.02 & 0.01 & 0.06 & 0.02 & 0.04 & 11.64 & 0.03 & 0.35 & 21,782 \\
\hline & 125 & 0 & 0 & 0 & 1 & 0 & 1 & 0 & 1 & 102.701 & 2,500 \\
\hline & 2500 & 1 & 1 & 1 & 9 & 1 & 5 & 1500 & 5 & 168.443 & $1,500,000$ \\
\hline \multirow{4}{*}{$\begin{array}{l}\text { Law } \\
n=779\end{array}$} & 610.24 & 0.32 & 0.38 & 0.89 & 5.21 & 0.51 & 2.75 & 402.31 & 1.49 & 139.39 & 741,126 \\
\hline & 18.53 & 0.02 & 0.02 & 0.01 & 0.06 & 0.02 & 0.04 & 12.22 & 0.03 & 0.33 & 237,29 \\
\hline & 125 & 0 & 0 & 0 & 1 & 0 & 1 & 0 & 1 & 105.029 & 2,500 \\
\hline & 2500 & 1 & 1 & 1 & 9 & 1 & 5 & 1500 & 5 & 164.646 & $1,500,000$ \\
\hline \multirow{4}{*}{$\begin{array}{l}\text { Social Sciences } \\
n=604\end{array}$} & 619.62 & 0.33 & 0.26 & 0.86 & 4.81 & 0.39 & 2.73 & 312.33 & 2.13 & 128.78 & 943,237 \\
\hline & 24.11 & 0.02 & 0.02 & 0.01 & 0.07 & 0.02 & 0.05 & 13.64 & 0.04 & 0.43 & 26,626 \\
\hline & 125 & 0 & 0 & 0 & 1 & 0 & 1 & 0 & 1 & 102.378 & 2,500 \\
\hline & 2500 & 1 & 1 & 1 & 9 & 1 & 5 & 1500 & 5 & 167.396 & $1,500,000$ \\
\hline \multirow{4}{*}{$\begin{array}{l}\text { Literature } \\
n=277\end{array}$} & 404.78 & 0.30 & 0.23 & 0.82 & 4.22 & 0.37 & 3.09 & 268.77 & 2.15 & 126.04 & 747,789 \\
\hline & 21.85 & 0.03 & 0.03 & 0.02 & 0.10 & 0.03 & 0.07 & 19.82 & 0.06 & 0.43 & 40,260 \\
\hline & 125 & 0 & 0 & 0 & 1 & 0 & 1 & 0 & 1 & 105.614 & 2,500 \\
\hline & 2500 & 1 & 1 & 1 & 9 & 1 & 5 & 1500 & 5 & 154.405 & $1,500,000$ \\
\hline \multirow[t]{4}{*}{ Total $n=6420$} & 474.22 & 0.32 & 0.28 & 0.86 & 4.54 & 0.48 & 2.98 & 297.18 & 1.91 & 132.37 & 715,288 \\
\hline & 5.58 & 0.01 & 0.01 & 0.00 & 0.02 & 0.01 & 0.01 & 4.01 & 0.01 & 0.12 & 8,318 \\
\hline & 125 & 0 & 0 & 0 & 1 & 0 & 1 & 0 & 1 & 100.612 & 2,500 \\
\hline & 2500 & 1 & 1 & 1 & 9 & 1 & 5 & 1500 & 5 & 168.443 & $1,500,000$ \\
\hline
\end{tabular}

Note: The statistics listed are the mean, standard deviation, minimum and the maximum, from top to bottom, respectively, for each cell. 
Table 4b

Descriptive statistics of the OSS data (science field).

\begin{tabular}{|c|c|c|c|c|c|c|c|c|c|c|c|}
\hline Major choice & Income & $\begin{array}{l}\text { Father self- } \\
\text { employed }\end{array}$ & $\begin{array}{l}\text { Father } \\
\text { public ss }\end{array}$ & $\begin{array}{l}\text { Father } \\
\text { private ss }\end{array}$ & $\begin{array}{l}\text { Father's } \\
\text { education }\end{array}$ & Male & $\begin{array}{l}\text { Number of } \\
\text { siblings }\end{array}$ & $\begin{array}{l}\text { Tutoring } \\
\text { hours }\end{array}$ & Times exam taken & $\begin{array}{l}\text { University } \\
\text { exam score }\end{array}$ & Population \\
\hline $\begin{array}{l}\text { Education } \\
n=1977\end{array}$ & $\begin{array}{l}335.80 \\
5.06 \\
125 \\
2500\end{array}$ & $\begin{array}{l}0.26 \\
0.01 \\
0 \\
1\end{array}$ & $\begin{array}{l}0.33 \\
0.01 \\
0 \\
1\end{array}$ & $\begin{array}{l}0.82 \\
0.01 \\
0 \\
1\end{array}$ & $\begin{array}{l}4.31 \\
0.04 \\
1 \\
9\end{array}$ & $\begin{array}{l}0.49 \\
0.01 \\
0 \\
1\end{array}$ & $\begin{array}{l}2.22 \\
0.03 \\
0 \\
4\end{array}$ & $\begin{array}{c}326.56 \\
6.90 \\
0 \\
1500\end{array}$ & $\begin{array}{l}1.64 \\
0.02 \\
1 \\
5\end{array}$ & $\begin{array}{c}144.46 \\
0.27 \\
103.292 \\
180.63\end{array}$ & $\begin{array}{r}501,543 \\
13,281 \\
2,500 \\
1,500,000\end{array}$ \\
\hline $\begin{array}{l}\text { Business } \\
n=303\end{array}$ & $\begin{array}{l}765.26 \\
35.40 \\
125 \\
2500\end{array}$ & $\begin{array}{l}0.37 \\
0.03 \\
0 \\
1\end{array}$ & $\begin{array}{l}0.32 \\
0.03 \\
0 \\
1\end{array}$ & $\begin{array}{l}0.91 \\
0.02 \\
0 \\
1\end{array}$ & $\begin{array}{l}5.56 \\
0.09 \\
2 \\
9\end{array}$ & $\begin{array}{l}0.62 \\
0.03 \\
0 \\
1\end{array}$ & $\begin{array}{l}1.60 \\
0.06 \\
0 \\
4\end{array}$ & $\begin{array}{c}479.54 \\
18.27 \\
0 \\
1500\end{array}$ & $\begin{array}{l}1.40 \\
0.04 \\
1 \\
3\end{array}$ & $\begin{array}{c}147.44 \\
0.95 \\
108.92 \\
178.747\end{array}$ & $\begin{array}{r}977,178 \\
36,530 \\
2,500 \\
1,500,000\end{array}$ \\
\hline $\begin{array}{l}\text { Econ-Pol-IR } \\
n=146\end{array}$ & $\begin{array}{l}694.35 \\
41.68 \\
125 \\
2500\end{array}$ & $\begin{array}{l}0.25 \\
0.04 \\
0 \\
1\end{array}$ & $\begin{array}{l}0.34 \\
0.04 \\
0 \\
1\end{array}$ & $\begin{array}{l}0.89 \\
0.03 \\
0 \\
1\end{array}$ & $\begin{array}{l}5.47 \\
0.13 \\
2 \\
9\end{array}$ & $\begin{array}{l}0.60 \\
0.04 \\
0 \\
1\end{array}$ & $\begin{array}{l}1.49 \\
0.08 \\
0 \\
4\end{array}$ & $\begin{array}{c}420.89 \\
28.99 \\
0 \\
1500\end{array}$ & $\begin{array}{l}1.57 \\
0.06 \\
1 \\
3\end{array}$ & $\begin{array}{c}147.10 \\
1.51 \\
108.126 \\
181.182\end{array}$ & $\begin{array}{r}1,046,353 \\
49,812 \\
2,500 \\
1,500,000\end{array}$ \\
\hline $\begin{array}{l}\text { Engineering } \\
n=2807\end{array}$ & $\begin{array}{l}600.29 \\
9.66 \\
125 \\
2500\end{array}$ & $\begin{array}{l}0.29 \\
0.01 \\
0 \\
1\end{array}$ & $\begin{array}{l}0.36 \\
0.01 \\
0 \\
1\end{array}$ & $\begin{array}{l}0.90 \\
0.01 \\
0 \\
1\end{array}$ & $\begin{array}{l}5.35 \\
0.03 \\
1 \\
9\end{array}$ & $\begin{array}{l}0.80 \\
0.01 \\
0 \\
1\end{array}$ & $\begin{array}{l}1.60 \\
0.02 \\
0 \\
4\end{array}$ & $\begin{array}{c}447.90 \\
6.37 \\
0 \\
1500\end{array}$ & $\begin{array}{l}1.46 \\
0.01 \\
1 \\
3\end{array}$ & $\begin{array}{c}155.26 \\
0.31 \\
108.065 \\
184.264\end{array}$ & $\begin{array}{r}876,436 \\
12,275 \\
2,500 \\
1,500,000\end{array}$ \\
\hline $\begin{array}{l}\text { Science } \\
n=1168\end{array}$ & $\begin{array}{l}476.03 \\
11.44 \\
125 \\
2500\end{array}$ & $\begin{array}{l}0.29 \\
0.01 \\
0 \\
1\end{array}$ & $\begin{array}{l}0.29 \\
0.01 \\
0 \\
1\end{array}$ & $\begin{array}{l}0.84 \\
0.01 \\
0 \\
1\end{array}$ & $\begin{array}{l}4.63 \\
0.05 \\
1 \\
9\end{array}$ & $\begin{array}{l}0.54 \\
0.01 \\
0 \\
1\end{array}$ & $\begin{array}{l}1.81 \\
0.03 \\
0 \\
4\end{array}$ & $\begin{array}{c}384.85 \\
10.16 \\
0 \\
1500\end{array}$ & $\begin{array}{l}1.82 \\
0.02 \\
1 \\
3\end{array}$ & $\begin{array}{c}138.28 \\
0.41 \\
105.326 \\
180.824\end{array}$ & $\begin{array}{r}893,236 \\
19,185 \\
2,500 \\
1,500,000\end{array}$ \\
\hline $\begin{array}{l}\text { Health } \\
n=2524\end{array}$ & $\begin{array}{l}447.70 \\
6.66 \\
125 \\
2500\end{array}$ & $\begin{array}{l}0.25 \\
0.01 \\
0 \\
1\end{array}$ & $\begin{array}{l}0.41 \\
0.01 \\
0 \\
1\end{array}$ & $\begin{array}{l}0.88 \\
0.01 \\
0 \\
1\end{array}$ & $\begin{array}{l}5.02 \\
0.03 \\
1 \\
9\end{array}$ & $\begin{array}{l}0.48 \\
0.01 \\
0 \\
1\end{array}$ & $\begin{array}{l}1.91 \\
0.02 \\
0 \\
4\end{array}$ & $\begin{array}{c}404.46 \\
6.43 \\
0 \\
1500\end{array}$ & $\begin{array}{l}1.48 \\
0.01 \\
1 \\
3\end{array}$ & $\begin{array}{c}154.71 \\
0.32 \\
103.893 \\
182.398\end{array}$ & $\begin{array}{r}639,504 \\
12,518 \\
2,500 \\
1,500,000\end{array}$ \\
\hline $\begin{array}{l}\text { Total } \\
n=8925\end{array}$ & $\begin{array}{l}489.43 \\
4.43 \\
125 \\
2500\end{array}$ & $\begin{array}{l}0.28 \\
0.00 \\
0 \\
1\end{array}$ & $\begin{array}{l}0.36 \\
0.01 \\
0 \\
1\end{array}$ & $\begin{array}{l}0.87 \\
0.00 \\
0 \\
1\end{array}$ & $\begin{array}{l}4.94 \\
0.02 \\
1 \\
9\end{array}$ & $\begin{array}{l}0.60 \\
0.01 \\
0 \\
1\end{array}$ & $\begin{array}{l}1.85 \\
0.01 \\
0 \\
4\end{array}$ & $\begin{array}{c}401.11 \\
3.50 \\
0 \\
1500\end{array}$ & $\begin{array}{l}1.55 \\
0.01 \\
1 \\
5\end{array}$ & $\begin{array}{c}150.09 \\
0.17 \\
103.292 \\
184.264\end{array}$ & $\begin{array}{r}734,786 \\
6,906 \\
2,500 \\
1,500,000\end{array}$ \\
\hline
\end{tabular}

Note: The statistics listed are the mean, standard deviation, minimum and the maximum, from top to bottom, respectively, for each cell. 
student chooses major $c$, we assume that $U_{c}^{i}$ is the maximum among $C$ utilities. Hence the statistical model is driven by the probability that choice $c$ is made, which can be written as Prob $\left(U_{c}^{i}>U_{k}^{i}\right)$ for all $k \neq \mathrm{c}$.

Let $Z$ be a random variable indicating the choice made. If the $C$ disturbances are independent and identically distributed with Weibull distribution $F\left(\varepsilon_{i c}\right)=\exp \left(e^{-\varepsilon_{i c}}\right)$, then normalizing $\beta_{0}=0$ :

$\operatorname{Pr}_{\mathrm{ic}}=\operatorname{Prob}\left(Z_{i}=c\right)=\frac{\mathrm{e}^{\beta_{c}^{\prime} x_{i}}}{\left(1+\sum_{K=1}^{C} \mathrm{e}^{\beta_{k}^{\prime} x_{i}}\right)}, \quad$ for $c=1,2, \ldots C$

$\operatorname{Pr}_{i 0}=\operatorname{Prob}\left(Z_{i}=0\right)=\frac{1}{1+\sum_{K=1}^{C} e^{\beta_{k}^{\prime} x_{i}}}$.

The model implies that we can compute $C$ (five in our study) relative risk ratios $P r_{i c} / P r_{i 0}=\mathrm{e}^{\beta_{c}^{\prime} x_{i}}$. The coefficients reported in Tables $5 \mathrm{a}$ and $5 \mathrm{~b}$ in the results section are $\mathrm{e}^{\beta_{c}^{\prime}}$ and indicate how the relative risk ratios change in response to an increase in $x$.

The $x$ matrix includes the characteristics of the student and his family. As explained in the theoretical framework section, we predict students coming from wealthier families to choose riskier careers. Therefore, we include in the $x$ matrix the logarithm of family income (income (ln)) as the indicator of wealth bequest that the individual receives from his family. We also include the number of siblings that the student has (no. of siblings) and the hours of tutoring that the student received before taking the exam (tutoring hours), since these variables are also indicators of the extent to which the student is supported by his family financially.

The $x$ matrix includes father's self-employment status (father self-employed), defined as a dummy variable that takes the value of 1 if self-employed or owns his business and 0 otherwise. According to the Turkish social security system, a person is either covered by the public sector program (called Emekli Sandigi), covered by a private sector program (called SSK or Bag-kur), or not covered at all. We therefore define two social security dummy variables. The "Father public ss" dummy is equal to 1 if father is covered by the public sector employees program and 0 otherwise. The "Father private ss" dummy takes the value of 1 if father is covered by private sector social security program and 0 otherwise. As explained in the theory section, father's selfemployment and social security status variables control for job preferences transmitted from parent to child.

To control for the possibility that women have different job preferences than men, we include in our regression a dummy variable (male) that is equal to 1 for men and 0 for women. Another control variable is the logarithm of the population of the area in which the student went to high school (population (ln)). This variable is included to control for the possibility that students coming from smaller towns have different job preferences. It is well known that in Turkey university characteristics such as location and reputation influence students program-university choices. Hence we also present results where we control for dummies over seventy universities.
To control for student's ability, we include in our regression the "OSS score" of the student, as explained in the theoretical framework section. We also include the "Times exam taken" variable. "Father's education" is included to control for the possible transmission of ability from parent to child. In order to see whether career choice decisions are guided by credit constraints rather than the channels predicted by our theory, we include as part of our robustness checks a dummy variable for being credit constrained which is equal to 1 if the student indicated that he plans to pay for his expenses by obtaining a scholarship/fellowship or a loan, and zero otherwise.

\section{Results}

We report the estimates of the multinomial logit model based on the TM data and the Science data separately in Tables $5 \mathrm{a}$ and $5 \mathrm{~b}$. The base category is education in the TM data and health in the Science data. We are primarily interested in estimating the impact of a change in parental income on relative risk ratio of choosing a given major relative to the base category, controlling for other determinants described in Section 4. We present two sets of results; one without university dummies, and one with dummies for over 70 universities.

The coefficients on the natural logarithm of income, which are calculated as $\exp (\hat{\beta})$, represent the impact of a percentage increase in income on the relative risk ratio (the probability of choosing each major relative to the base category), so that a coefficient of one for a given major means that increasing income has no impact on choosing that major relative to the base category whereas a coefficient above one implies a positive and a coefficient below one a negative impact. In Table 5a, without university dummies, the coefficient on income for a student who chose business major is about 1.98 . This means that a $100 \%$ increase in parental income will increase the relative risk ratio by $98 \%$. In other words, doubling parental income almost doubles the probability of majoring in business relative to the probability of majoring in education.

We find that a student whose father is self-employed is about $60 \%$ more likely to choose business major as opposed to the education major. Also interestingly, a student whose father is covered by public sector social security is almost $50 \%$ less likely to choose business over education. ${ }^{17}$ Father's education, which is a measure of parental ability that is likely to be correlated across generations, increases the relative probability of choosing business over education. This is consistent with our theoretical framework that ability increases returns to a career in the private sector.

In addition to its impact on the probability of choosing business major - a natural candidate for someone aspiring

\footnotetext{
17 Tansel (2005) used a specification similar to including self employment and social security status of the father. In a multinomial model of selection into occupation in the public sector, state owned enterprises or private sector in Turkey, she found that for an individual the presence of a household member (father or other) who is employed in a given sector increases significantly the probability of choosing an occupation in the same sector. This finding indicates the importance of passing on knowhow or genetic abilities among household members in career choice.
} 
Table 5a

Determinants of choosing a college major in the Turkish-Math data. Multinomial logit model:base category:education.

\begin{tabular}{|c|c|c|c|c|c|c|c|c|c|c|}
\hline & \multicolumn{5}{|c|}{ Without university dummies } & \multicolumn{5}{|c|}{ With university dummies } \\
\hline & Business & Econ-Pol-IR & Law & Social Sciences & Literature & Business & Econ-Pol-IR & Law & Social Sciences & Literature \\
\hline Income (In) & $\begin{array}{l}1.977^{* * *} \\
(0.15)\end{array}$ & $\begin{array}{l}1.884^{* * *} \\
(0.12)\end{array}$ & $\begin{array}{l}1.750^{* * *} \\
(0.12)\end{array}$ & $\begin{array}{l}1.891^{* * *} \\
(0.14)\end{array}$ & $\begin{array}{l}1.151 \\
(0.12)\end{array}$ & $\begin{array}{l}1.638^{* * *} \\
(0.14)\end{array}$ & $\begin{array}{l}1.761^{* * *} \\
(0.14)\end{array}$ & $\begin{array}{l}1.385^{* * *} \\
(0.12)\end{array}$ & $\begin{array}{l}1.699^{* * *} \\
(0.17)\end{array}$ & $\begin{array}{l}1.145 \\
(0.13)\end{array}$ \\
\hline Father self-employed & $\begin{array}{l}1.604^{* * *} \\
(0.18)\end{array}$ & $\begin{array}{l}0.999 \\
(0.10)\end{array}$ & $\begin{array}{l}1.345^{* *} \\
(0.14)\end{array}$ & $\begin{array}{l}0.998 \\
(0.11)\end{array}$ & $\begin{array}{l}0.868 \\
(0.13)\end{array}$ & $\begin{array}{l}1.492^{* *} \\
(0.18)\end{array}$ & $\begin{array}{l}0.971 \\
(0.11)\end{array}$ & $\begin{array}{l}1.307^{*} \\
(0.17)\end{array}$ & $\begin{array}{l}0.8 \\
(0.11)\end{array}$ & $\begin{array}{l}0.8 \\
(0.13)\end{array}$ \\
\hline Father public ss & $\begin{array}{l}0.499^{* * *} \\
(0.07)\end{array}$ & $\begin{array}{l}0.627^{* * *} \\
(0.07)\end{array}$ & $\begin{array}{l}1.02 \\
(0.12)\end{array}$ & $\begin{array}{l}0.538^{* * * *} \\
(0.07)\end{array}$ & $\begin{array}{l}0.675^{*} \\
(0.13)\end{array}$ & $\begin{array}{l}0.525^{* * *} \\
(0.08)\end{array}$ & $\begin{array}{l}0.643^{* * *} \\
(0.08)\end{array}$ & $\begin{array}{l}1.15 \\
(0.17)\end{array}$ & $\begin{array}{l}0.423^{* * *} \\
(0.07)\end{array}$ & $\begin{array}{l}0.600^{*} \\
(0.12)\end{array}$ \\
\hline Father private ss & $\begin{array}{l}1.39 \\
(0.25)\end{array}$ & $\begin{array}{l}0.94 \\
(0.13)\end{array}$ & $\begin{array}{l}0.81 \\
(0.12)\end{array}$ & $\begin{array}{l}0.668^{* *} \\
(0.10)\end{array}$ & $\begin{array}{l}0.73 \\
(0.13)\end{array}$ & $\begin{array}{l}1.578^{*} \\
(0.30)\end{array}$ & $\begin{array}{l}0.95 \\
(0.15)\end{array}$ & $\begin{array}{l}0.90 \\
(0.16)\end{array}$ & $\begin{array}{l}0.74 \\
(0.14)\end{array}$ & $\begin{array}{l}0.80 \\
(0.16)\end{array}$ \\
\hline Father's education & $\begin{array}{l}1.208^{* * *} \\
(0.05)\end{array}$ & $\begin{array}{l}1.142^{* * *} \\
(0.04)\end{array}$ & $\begin{array}{l}1.217^{* * *} \\
(0.04)\end{array}$ & $\begin{array}{l}1.170^{* * *} \\
(0.04)\end{array}$ & $\begin{array}{l}1.029 \\
(0.06)\end{array}$ & $\begin{array}{l}1.218^{* * * *} \\
(0.05)\end{array}$ & $\begin{array}{l}1.162^{* * *} \\
(0.04)\end{array}$ & $\begin{array}{l}1.190^{* * * *} \\
(0.05)\end{array}$ & $\begin{array}{l}1.169^{* *} \\
(0.06)\end{array}$ & $\begin{array}{l}1.113 \\
(0.07)\end{array}$ \\
\hline Male & $\begin{array}{l}3.895^{* * *} \\
(0.39)\end{array}$ & $\begin{array}{l}3.189^{* * * *} \\
(0.27)\end{array}$ & $\begin{array}{l}1.928^{* * *} \\
(0.17)\end{array}$ & $\begin{array}{l}1.128 \\
(0.11)\end{array}$ & $\begin{array}{l}0.923 \\
(0.12)\end{array}$ & $\begin{array}{l}3.954^{* * * *} \\
(0.45)\end{array}$ & $\begin{array}{l}3.483^{* * * *} \\
(0.34)\end{array}$ & $\begin{array}{l}1.598^{* * *} \\
(0.18)\end{array}$ & $\begin{array}{l}1.402^{* *} \\
(0.18)\end{array}$ & $\begin{array}{l}1.133 \\
(0.17)\end{array}$ \\
\hline No.of siblings & $\begin{array}{l}0.732^{* * *} \\
(0.04)\end{array}$ & $\begin{array}{l}0.830^{* * * *} \\
(0.03)\end{array}$ & $\begin{array}{l}0.981 \\
(0.04)\end{array}$ & $\begin{array}{l}0.808^{* * * *} \\
(0.04)\end{array}$ & $\begin{array}{l}0.935 \\
(0.06)\end{array}$ & $\begin{array}{l}0.775^{* * * *} \\
(0.04)\end{array}$ & $\begin{array}{l}0.859^{* *} \\
(0.04)\end{array}$ & $\begin{array}{l}1.017 \\
(0.06)\end{array}$ & $\begin{array}{l}0.803^{* * *} \\
(0.05)\end{array}$ & $\begin{array}{l}0.991 \\
(0.07)\end{array}$ \\
\hline Tutoring hours & $\begin{array}{l}1.000^{*} \\
(0.00)\end{array}$ & $\begin{array}{l}1.000^{* * * *} \\
(0.00)\end{array}$ & $\begin{array}{l}1.001^{* * *} \\
(0.00)\end{array}$ & $\begin{array}{l}1.000 \\
(0.00)\end{array}$ & $\begin{array}{l}1.001^{*} \\
(0.00)\end{array}$ & $\begin{array}{l}1.000^{*} \\
(0.00)\end{array}$ & $\begin{array}{l}1.000^{* *} \\
(0.00)\end{array}$ & $\begin{array}{l}1.000^{* *} \\
(0.00)\end{array}$ & $\begin{array}{l}1.000 \\
(0.00)\end{array}$ & $\begin{array}{l}1.000 \\
(0.00)\end{array}$ \\
\hline Times exam taken & $\begin{array}{l}1.068 \\
(0.06)\end{array}$ & $\begin{array}{l}1.058 \\
(0.05)\end{array}$ & $\begin{array}{l}0.713^{* * *} \\
(0.04)\end{array}$ & $\begin{array}{l}1.280^{* * * *} \\
(0.06)\end{array}$ & $\begin{array}{l}1.154^{*} \\
(0.07)\end{array}$ & $\begin{array}{l}1.130^{*} \\
(0.07)\end{array}$ & $\begin{array}{l}1.035 \\
(0.05)\end{array}$ & $\begin{array}{l}0.693^{* * *} \\
(0.05)\end{array}$ & $\begin{array}{l}1.443^{* * *} \\
(0.09)\end{array}$ & $\begin{array}{l}1.221^{* *} \\
(0.09)\end{array}$ \\
\hline OSS score & $\begin{array}{l}1.026^{* * *} \\
(0.01)\end{array}$ & $\begin{array}{l}1.039^{* * *} \\
(0.00)\end{array}$ & $\begin{array}{l}1.089^{* * *} \\
(0.01)\end{array}$ & $\begin{array}{l}0.968^{* * *} \\
(0.01)\end{array}$ & $\begin{array}{l}0.928^{* * *} \\
(0.01)\end{array}$ & $\begin{array}{l}1.048^{* * * *} \\
(0.01)\end{array}$ & $\begin{array}{l}1.054^{* * *} \\
(0.01)\end{array}$ & $\begin{array}{l}1.122^{* * *} \\
(0.01)\end{array}$ & $\begin{array}{l}0.929^{* * *} \\
(0.01)\end{array}$ & $\begin{array}{l}0.907^{* * *} \\
(0.01)\end{array}$ \\
\hline Population (In) & $\begin{array}{l}1.303^{* * *} \\
(0.04)\end{array}$ & $\begin{array}{l}1.326^{* * *} \\
(0.04)\end{array}$ & $\begin{array}{l}1.042 \\
(0.03)\end{array}$ & $\begin{array}{l}1.265^{* * *} \\
(0.04)\end{array}$ & $\begin{array}{l}1.143^{* * *} \\
(0.04)\end{array}$ & $\begin{array}{l}1.291^{* * *} \\
(0.04)\end{array}$ & $\begin{array}{l}1.338^{* * * *} \\
(0.04)\end{array}$ & $\begin{array}{l}0.994 \\
(0.03)\end{array}$ & $\begin{array}{l}1.256^{* * *} \\
(0.05)\end{array}$ & $\begin{array}{l}1.137^{* *} \\
(0.05)\end{array}$ \\
\hline University dummies & No & No & No & No & No & Yes & Yes & Yes & Yes & Yes \\
\hline Pseudo R2 & 0.13 & & & & & 0.39 & & & & \\
\hline Number of Observations & 6420 & & & & & 6412 & & & & \\
\hline
\end{tabular}

Source: Authors' calculations based on the 2002 OSS data.

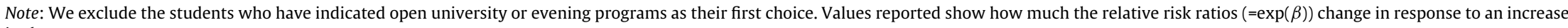
in the regressors.

* Statistical significance at $1 \%$.

** Statistical significance at $5 \%$.

*** Statistical significance at $10 \%$. 
Table 5b

Determinants of choosing a college major in the science data. Multinomial logit model:base category:health.

\begin{tabular}{|c|c|c|c|c|c|c|c|c|c|c|}
\hline & \multicolumn{5}{|c|}{ Without university dummies } & \multicolumn{5}{|c|}{ With university dummies } \\
\hline & Education & Business & icon-Pol-IR & Engineering & Science & Education & Business & Econ-Pol-IR & Engineering & Science \\
\hline Income (In) & $\begin{array}{l}0.840^{* *} \\
(0.05)\end{array}$ & $\begin{array}{l}2.161^{* * *} \\
(0.22)\end{array}$ & $\begin{array}{l}2.327^{* * *} \\
(0.34)\end{array}$ & $\begin{array}{l}1.426^{* * *} \\
(0.07)\end{array}$ & $\begin{array}{l}1.249^{* * *} \\
(0.08)\end{array}$ & $\begin{array}{l}0.857^{*} \\
(0.06)\end{array}$ & $\begin{array}{l}1.874^{* * *} \\
(0.22)\end{array}$ & $\begin{array}{l}2.160^{* * *} \\
(0.35)\end{array}$ & $\begin{array}{l}1.353^{* * *} \\
(0.09)\end{array}$ & $\begin{array}{l}1.179^{*} \\
(0.09)\end{array}$ \\
\hline Father self-employed & $\begin{array}{l}0.782^{* *} \\
(0.06)\end{array}$ & $\begin{array}{l}1.406^{*} \\
(0.21)\end{array}$ & $\begin{array}{l}0.76 \\
(0.17)\end{array}$ & $\begin{array}{l}1.183^{*} \\
(0.09)\end{array}$ & $\begin{array}{l}0.937 \\
(0.09)\end{array}$ & $\begin{array}{l}0.790^{*} \\
(0.07)\end{array}$ & $\begin{array}{l}1.328 \\
(0.22)\end{array}$ & $\begin{array}{l}0.66 \\
(0.16)\end{array}$ & $\begin{array}{l}1.204 \\
(0.11)\end{array}$ & $\begin{array}{l}0.929 \\
(0.10)\end{array}$ \\
\hline Father public ss & $\begin{array}{l}1.08 \\
(0.09)\end{array}$ & $\begin{array}{l}0.584^{* *} \\
(0.10)\end{array}$ & $\begin{array}{l}0.550^{* *} \\
(0.12)\end{array}$ & $\begin{array}{l}0.649^{* * *} \\
(0.05)\end{array}$ & $\begin{array}{l}0.711^{* * *} \\
(0.07)\end{array}$ & $\begin{array}{l}1.13 \\
(0.11)\end{array}$ & $\begin{array}{l}0.71 \\
(0.13)\end{array}$ & $\begin{array}{l}0.67 \\
(0.16)\end{array}$ & $\begin{array}{l}0.765^{* *} \\
(0.08)\end{array}$ & $\begin{array}{l}0.83 \\
(0.10)\end{array}$ \\
\hline Father private ss & $\begin{array}{l}0.93 \\
(0.09)\end{array}$ & $\begin{array}{l}1.06 \\
(0.24)\end{array}$ & $\begin{array}{l}0.79 \\
(0.23)\end{array}$ & $\begin{array}{l}1.01 \\
(0.10)\end{array}$ & $\begin{array}{l}0.86 \\
(0.10)\end{array}$ & $\begin{array}{l}0.89 \\
(0.10)\end{array}$ & $\begin{array}{l}1.06 \\
(0.26)\end{array}$ & $\begin{array}{l}0.72 \\
(0.22)\end{array}$ & $\begin{array}{l}0.96 \\
(0.12)\end{array}$ & $\begin{array}{l}0.80 \\
(0.11)\end{array}$ \\
\hline Father's education & $\begin{array}{l}0.866^{* * *} \\
(0.02)\end{array}$ & $\begin{array}{l}1.120^{*} \\
(0.05)\end{array}$ & $\begin{array}{l}1.046 \\
(0.07)\end{array}$ & $\begin{array}{l}1.077^{* *} \\
(0.03)\end{array}$ & $\begin{array}{l}0.920^{* *} \\
(0.03)\end{array}$ & $\begin{array}{l}0.840^{* * *} \\
(0.03)\end{array}$ & $\begin{array}{l}1.101 \\
(0.06)\end{array}$ & $\begin{array}{l}1.04 \\
(0.08)\end{array}$ & $\begin{array}{l}1.059 \\
(0.03)\end{array}$ & $\begin{array}{l}0.912^{* *} \\
(0.03)\end{array}$ \\
\hline Male & $\begin{array}{l}1.082 \\
(0.07)\end{array}$ & $\begin{array}{l}2.631^{* * *} \\
(0.34)\end{array}$ & $\begin{array}{l}2.218^{* * * *} \\
(0.40)\end{array}$ & $\begin{array}{l}5.312^{* * * *} \\
(0.35)\end{array}$ & $\begin{array}{l}1.789^{* * *} \\
(0.14)\end{array}$ & $\begin{array}{l}1.243^{* *} \\
(0.10)\end{array}$ & $\begin{array}{l}3.90^{* * *} \\
(0.58)\end{array}$ & $\begin{array}{l}3.593^{* * * *} \\
(0.69)\end{array}$ & $\begin{array}{l}7.519^{* * *} \\
(0.66)\end{array}$ & $\begin{array}{l}2.628^{* * *} \\
(0.25)\end{array}$ \\
\hline No.of siblings & $\begin{array}{l}1.075^{*} \\
(0.03)\end{array}$ & $\begin{array}{l}0.92 \\
(0.06)\end{array}$ & $\begin{array}{l}0.760^{* *} \\
(0.07)\end{array}$ & $\begin{array}{l}0.798^{* * *} \\
(0.02)\end{array}$ & $\begin{array}{l}0.832^{* * *} \\
(0.03)\end{array}$ & $\begin{array}{l}1.003 \\
(0.04)\end{array}$ & $\begin{array}{l}1.029 \\
(0.08)\end{array}$ & $\begin{array}{l}0.9 \\
(0.09)\end{array}$ & $\begin{array}{l}0.881^{* *} \\
(0.03)\end{array}$ & $\begin{array}{l}0.92 \\
(0.04)\end{array}$ \\
\hline Tutoring hours & $\begin{array}{l}1.000 \\
(0.00)\end{array}$ & $\begin{array}{l}1.000 \\
(0.00)\end{array}$ & $\begin{array}{l}1.000 \\
(0.00)\end{array}$ & $\begin{array}{l}1.000 \\
(0.00)\end{array}$ & $\begin{array}{l}1.000 \\
(0.00)\end{array}$ & $\begin{array}{l}1.000 \\
(0.00)\end{array}$ & $\begin{array}{l}1.000 \\
(0.00)\end{array}$ & $\begin{array}{l}1.000 \\
(0.00)\end{array}$ & $\begin{array}{l}1.000 \\
(0.00)\end{array}$ & $\begin{array}{l}1.000 \\
(0.00)\end{array}$ \\
\hline Times exam taken & $\begin{array}{l}0.965 \\
(0.05)\end{array}$ & $\begin{array}{l}0.745^{* *} \\
(0.08)\end{array}$ & $\begin{array}{l}1.159 \\
(0.16)\end{array}$ & $\begin{array}{l}0.996 \\
(0.05)\end{array}$ & $\begin{array}{l}1.395^{* * *} \\
(0.08)\end{array}$ & $\begin{array}{l}0.957 \\
(0.06)\end{array}$ & $\begin{array}{l}0.976 \\
(0.12)\end{array}$ & $\begin{array}{l}1.389^{*} \\
(0.21)\end{array}$ & $\begin{array}{l}1.123 \\
(0.07)\end{array}$ & $\begin{array}{l}1.665^{* * *} \\
(0.11)\end{array}$ \\
\hline OSS score & $\begin{array}{l}0.961^{* * *} \\
(0.00)\end{array}$ & $\begin{array}{l}0.959^{* * *} \\
(0.00)\end{array}$ & $\begin{array}{l}0.964^{* * *} \\
(0.01)\end{array}$ & $\begin{array}{l}0.992^{* * *} \\
(0.00)\end{array}$ & $\begin{array}{l}0.932^{* * *} \\
(0.00)\end{array}$ & $\begin{array}{l}0.939^{* * *} \\
(0.00)\end{array}$ & $\begin{array}{l}0.913^{* * *} \\
(0.00)\end{array}$ & $\begin{array}{l}0.917^{* * *} \\
(0.01)\end{array}$ & $\begin{array}{l}0.951^{* * *} \\
(0.00)\end{array}$ & $\begin{array}{l}0.895^{* * *} \\
(0.00)\end{array}$ \\
\hline Population (In) & $\begin{array}{l}0.930^{* * *} \\
(0.02)\end{array}$ & $\begin{array}{l}1.263^{* * * *} \\
(0.06)\end{array}$ & $\begin{array}{l}1.428^{* * * *} \\
(0.10)\end{array}$ & $\begin{array}{l}1.211^{* * *} \\
(0.02)\end{array}$ & $\begin{array}{l}1.250^{* * *} \\
(0.03)\end{array}$ & $\begin{array}{l}0.934^{* *} \\
(0.02)\end{array}$ & $\begin{array}{l}1.219^{* * * *} \\
(0.06)\end{array}$ & $\begin{array}{l}1.384^{* * * *} \\
(0.10)\end{array}$ & $\begin{array}{l}1.218^{* * *} \\
(0.03)\end{array}$ & $\begin{array}{l}1.267^{* * *} \\
(0.04)\end{array}$ \\
\hline University dummies & No & No & No & No & No & Yes & Yes & Yes & Yes & Yes \\
\hline $\begin{array}{l}\text { Pseudo R2 } \\
\text { Number of Observations }\end{array}$ & $\begin{array}{l}0.13 \\
8925\end{array}$ & & & & & $\begin{array}{l}0.37 \\
8870\end{array}$ & & & & \\
\hline
\end{tabular}

Source: Authors' calculations based on the 2002 OSS data.

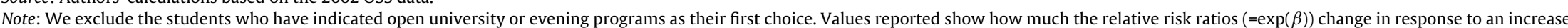
in the regressors.

Statistical significance at $1 \%$

Statistical significance at $5 \%$

*** Statistical significance at $10 \%$. 
to be self-employed, father's self-employment status has also a positive impact on the relative probability of choosing law major over education. Given that law graduates have the option to start their private law practices which is a form of self-employment, this result is not unexpected.

Given our theoretical framework, we expect father's public sector social security status to decrease the relative probability of choosing majors that lead to careers in private sector as opposed to the education major that leads to a career in the public sector. This is indeed what we find econometrically. The relative probability of choosing almost all majors over education decreases for those with fathers that have public social security status. The only exception is the law major for which there is no significant difference. Note that legal professionals have lower unemployment rates than managers and economists according to Turkish 2000 Census statistics (Table 2). Furthermore, law majors who choose to become judges and prosecutors are employed by the public sector. Hence, the relative job security of law majors and the potential for public sector employment may make law a desirable major for those with public sector job preferences.

Interestingly, father's private social security status variable does not have a statistically significant impact on choosing business, Econ-Pol-IR, law or literature over education, although the magnitude of the effect is quite large for business majors. (The omitted category is father's not having any social security). This is in sharp contrast with the effect that we observe for the father's public social security variable. This could be due to the fact that the ownership rate of some sort of private sector social security is quite high, so that the effect of this variable is hard to distinguish from the effect of a constant. Regardless, this strengthens our argument that father's job preferences as measured by his public sector social security status plays an important role in the student's choice of a major that leads to public sector (or low unemployment risk) employment as opposed to a major that leads to private sector employment.

Parental income also increases the relative risk ratio of choosing Econ-Pol-IR over education consistent with the evidence presented in Section 5 that Econ-Pol-IR is a higher return higher risk major relative to education. Although we do not have any data on the labor market outcomes of social science graduates, the similarity in coefficient estimates to those of Econ-Pol-IR suggests that careers in these two areas have similar return and risk characteristics. Parental income does not affect the relative risk ratio of choosing literature over education. This is not very surprising given that many literature graduates seek employment as teachers and hence the two majors are likely to have similar labor income streams. However, in order to be employed as public school teachers, literature graduates are required to complete a Master's program in pedagogy which lowers the present discounted value of potential earnings. Hence we would expect the literature major to be less desirable than teaching. Consistent with our expectations, students who choose this major are likely to have lower OSS scores relative to education.

It is important to note that, the OSS score, which is the only determinant of a student's placement in a univer- sity program, is statistically significant in all regressions. One can interpret this result in two ways: First, if OSS score measures a component of ability, then, consistent with the theoretical prediction, higher ability individuals choose high-risk high return careers such as business over education. Second, the OSS score may be a constraint on major choice. If this is the case, then it appears that less constrained students (those with higher scores) choose business over education. However, economically, the magnitude of the effect is rather small. For example, a 1 point increase in the OSS score makes a student more likely to choose business over education by only 2.6 percent. ${ }^{18}$ The small economic significance of this result may also be due to lack of university level controls.

Hence, in our second set of results, we control for university dummies for over seventy universities. While there is some change in the magnitude of the coefficients, our results essentially remain the same. For example, the coefficient on parental income changes from 1.98 to 1.64 , while the coefficient on father's self-employment status changes from 1.60 to 1.49 for the business major. As expected, the impact of OSS score on the relative probability of choosing a specific major over education increases - from $2.6 \%$ to $8.4 \%$ - once we control for university dummies. Although the effect is larger than previously, its economic impact is still small compared to the impact of income or other father specific variables. There does not seem to be a significant effect of private tutoring hours on the choice between business and education majors. The results on the OSS score and tutoring hours support our suggestion that, business does not first order stochastically dominate education.

The estimates for other control variables are consistent with our observations of descriptive statistics. Being male, having a more educated father, having fewer siblings, or coming from a more populated area all increase the relative probability of choosing business over education consistent with our theoretical predictions. In summary, controlling for university dummies, the students' choice set as well as a number of socio-economic characteristics, we are able to pin down the importance of parental income, father's selfemployment status and father's social security status on choosing careers that are perceived to have riskier income streams.

We next turn our attention to the university applicants that are from the science field of their high schools. The estimates for these students are presented in Table 5b. Here our categories are Education, Business, Econ-Pol-IR, Engineering, Science and Health (the base category). Our control variables are the same as in Table 5 a with the exception that private tutoring hours for math and science and OSS quantitative scores are used since engineering and most health degrees require OSS quantitative score, which is based on math and science test scores of students. We again present results with and without university dummies. Since con-

\footnotetext{
18 In 2002, a 1-point increase in the OSS score represented a 0.3-1 percentile increase in the ranking of the student (OSYM, 2002). This would mean that a 1-point increase in the OSS score enabled the candidate to get ahead of 510-1700 students in the ranking. Since departmental quotas are in the vicinity of 50-200, such a small difference in the OSS score can have great implications for the student's admittance.
} 
trolling for university dummies gives us more conservative estimates we discuss only these results.

Our results show that increasing income by $100 \%$ increases the relative probability of choosing engineering over health by $35 \%$. Increasing income by $100 \%$ increases the relative probability of choosing business by $87 \%$ while it decreases the probability of choosing education over health by $14 \%$. The coefficient on education is significant only at $10 \%$. Hence the effect of income on the relative probability of choosing education over health is small, and provides further evidence on the similarity of these two majors in terms of their public sector employment prospects and low risk income streams.

As students from the science field typically choose majors in health, engineering and science, there are not too many observations for business and Econ-PolIR majors (303 for business, 146 for Econ-Pol-IR) in the science data. When we include over 70 university dummies, naturally some of the significant coefficients become insignificant. For example, the positive impact of father's self-employment status on choosing business which was significant in the regression without university dummies, becomes insignificant once university dummies are included. Hence we do not want to make too much of our results on business and Econ-Pol-IR in these estimations. We present them mainly to have similar majors across Tables $5 \mathrm{a}$ and $5 \mathrm{~b}$.

Interestingly, father's self-employment status does not have any impact on choosing engineering over health major. But father's public sector social security status decreases the probability of choosing engineering over health by $23 \%$. Increasing the OSS score by 1 point decreases the relative probability of choosing engineering over health by $0.5 \%$. The estimates for the other control variables are similar to those for the TM data. In particular, being male, having a more educated father, having fewer siblings, or coming from a more populated area increases the relative probability of choosing engineering over health.

\subsection{Further robustness checks}

\subsubsection{Measurement error in income}

Since data on parental income are based on a survey of students, and students may apply for financial aid if they are accepted to a program, there is some concern that those who intend to apply for aid may underreport their income. Hence we have re-done our estimations by excluding students that choose the lowest category of income on the survey questionnaire. Both the statistical and economic significance of our results remain fairly comparable. If anything, the economic significance of parental income is higher when the lowest income students are omitted from the regression. Results are not shown but available upon request.

\subsubsection{Controlling for the transmission of father's job preferences to the offspring}

Here we restrict the sample to students whose fathers are at most high school graduates. By doing this, we restrict the effect of parental job preferences on the child's career choice, presuming that a college degree will enable the child to choose a different career from his/her less educated father. The results essentially remain the same. The only noteworthy difference is that father's self-employment status no longer has any effect on the choice of law major over education. This is expected since by restricting data in this way we drop fathers who have their own law practices. These results are not shown but available upon request.

\subsubsection{Model specification}

We have estimated our regressions using the multinomial probit model. Marginal effects from the multinomial logit model and the multinomial probit model are estimated and found to be very similar. We have also estimated an ordinary logit model where we restricted sample to education and business majors in the TM data and health and engineering majors in the Science data. The coefficients for business and engineering majors are very similar to their counterparts in the multinomial logit model. These two sets of results are not presented here but available upon request.

\subsubsection{Credit constraints}

We test for the possibility that credit constraints may influence major choice by using a dummy variable which is equal to 1 if the student indicated that he plans to pay for his expenses by obtaining a scholarship/fellowship or a loan, and zero otherwise. While the coefficients on other variables remain essentially the same, the credit variable is not significant in regressions. Hence students who plan to obtain these fellowships/loans are not more likely to choose education over other majors. Results are not shown but available upon request.

\section{Conclusion}

In this paper, we find strong evidence that in Turkey family income, father's self-employment and social security status are important determinants of choosing a major with a higher labor income risk such as business over a less risky one such as education or health.

The impact of parental income and risk on career choice has important policy implications for countries with significant income inequalities. Poor students may be systematically more likely to avoid risky human capital investments, even if these investments entail high expected personal returns. To the extent that high personal returns also imply high social returns, it may be efficient for governments to provide larger subsidies for these investments to poor students. Furthermore, if poor students are less likely to undertake educational investments that entail high risk and high expected return, initial differences in family income may cause long-run economic inequality that persists for generations. This insight adds another reason for government involvement in the education sector.

\section{Appendix A. Appendix}

Table A1 
Table A1

OLS regression estimates of monthly compensation on individual and parental characteristics of Bilkent University graduates.

\begin{tabular}{|c|c|}
\hline & Coefficient (StdError) \\
\hline \multirow[t]{2}{*}{ Sex } & $677.7792^{* * *}$ \\
\hline & $(137.53)$ \\
\hline \multirow[t]{2}{*}{ Job experience } & $200.3315^{* * *}$ \\
\hline & $(38.38)$ \\
\hline \multirow[t]{2}{*}{ Experience } & $251.2484^{* * *}$ \\
\hline & $(40.78)$ \\
\hline \multirow[t]{2}{*}{ Age } & $-417.133^{* *}$ \\
\hline & $(182.76)$ \\
\hline \multirow[t]{2}{*}{ Age squared } & $9.041082^{* *}$ \\
\hline & $(2.93)$ \\
\hline \multirow[t]{2}{*}{ Dummy: father primary school graduate } & 1018.533 \\
\hline & $(736.11)$ \\
\hline \multirow[t]{2}{*}{ Dummy: father junior high school graduate } & 745.8175 \\
\hline & $(790.55)$ \\
\hline \multirow[t]{2}{*}{ Dummy: father high school graduate } & 1082.336 \\
\hline & $(729.17)$ \\
\hline \multirow[t]{2}{*}{ Dummy: father vocational school graduate } & 834.5121 \\
\hline & $(779.77)$ \\
\hline \multirow[t]{2}{*}{ Dummy: father university graduate } & $1314.737^{*}$ \\
\hline & $(713.07)$ \\
\hline \multirow{2}{*}{ Dummy: father master's degree } & $1523.697^{* *}$ \\
\hline & $(737.46)$ \\
\hline \multirow[t]{2}{*}{ Dummy: father Ph.D. degree } & 914.1692 \\
\hline & $(738.30)$ \\
\hline \multirow[t]{2}{*}{ Constant } & $5294.225^{*}$ \\
\hline & $(2890.58)$ \\
\hline Adj. $R$-squared & 0.3859 \\
\hline$N$ & 682 \\
\hline
\end{tabular}

Note: Data are from the survey that we conducted on Bilkent University graduates.

* Statistical significance at $10 \%$.

** Statistical significance at $5 \%$.

*** Statistical significance at $1 \%$.

\section{References}

Alper, Z., \& Ozdemir, H. (2004). Uludag Universitesi Tip Fakultesini Tercih Eden Ogrencilerin Kimi Sosyo-Demografik Ozellikleri ve Meslege Bakis Acilari [The socio-demographic characteristics and the career views of students at the Uludag School of Medicine]. Uludag Universitesi Tip Fakultesi Dergisi, 30(2), 93-96.

Angrist, J. D., \& Krueger, A. B. (1991). Does compulsory school attendance affect schooling and earnings? Quarterly Journal of Economics, 84(5), 1157-1173.

Arcidiacono, P. (2004). Ability sorting and the returns to college major. Journal of Econometrics, 121, 343-375.

Ashenfelter, O., \& Krueger, A. B. (1994). Estimates of the economic return to schooling from a new sample of twins. American Economic Review, 84(December (5)), 1157-1173.

Becker, G. S. (1964). Human capital: A theoretical and empirical analysis, with special reference to education. New York: Columbia University Press.

Berger, M. C. (1988). Predicted future earnings and choice of college major. Industrial and Labor Relations Review, 41(April (3)), 418429.

Boskin, M. (1974). A conditional logit model of occupational choice. The Journal of Political Economy, 82(March-April (2)), 389-398.

Carmichael, F. (2000). Intergenerational mobility and occupational status in Britain. Applied Economics Letters, 7(June (6)), 391-396.
Dohmen, T., Falk, A., Huffman, D., Sunde, U., 2006. The Intergenerational Transmission of Risk and Trust Attitudes. IZA Discussion Paper No. 2380 (October).

Dunn, T., \& Holtz-Eakin, D. (2000). Financial capital, human capital, and the transition to self-employment: Evidence from intergenerational links. Journal of Labor Economics, 18(April (2)), 282-305.

Evans, D. S., \& Leighton, L. (1989). Some empirical aspects of entrepreneurship. American Economic Review, 79(June (3)), 19-35.

Guler, B. A. (2003). Turkiye'de Kamu Personel Rejimi Esaslari. In Proceedings of the Symposium on the Restructuring of the Turkish Personnel Regime 22-23 Subat (February), Ankara, Turkey,

Jianakoplos, N. A., \& Bernasek, A. (1998). Are women more risk averse? Economic Inquiry, 36, 620-630.

Judd, K. L., 2000. Is education as good as gold? A portfolio analysis of human capital investment. Working Paper. http://bucky.stanford. edu/papers/edumay.pdf.

Kerckhoff, A. C., Campbell, R. T., \& Winfield-Laird, I. (1985). Social mobility in Great Britain and the United States. American Journal of Sociology, 91(September (2)), 281-308.

Levhari, D., \& Weiss, Y. (1974). The effect of risk on the investment in human capital. The American Economic Review, 64(December (6)), 950-963.

Levy, H. (1994). Absolute and relative risk aversion: An experimental study. Journal of Risk and Uncertainty, 8, 289-307.

Liu, J.-T., Chou, S.-Y., \& Liu, J.-L. (2006). Asymmetries in progression in higher education in Taiwan: Parental education and income effects. Economics of Education Review, 25(December (6)), 647-658.

Ministry of Health, 2005. Saglik Istatistikleri (Health Statistics) 2004. Saglik Bakanligi Yayin No. (Ministry of Health Publication No.) 677, Aralık (December)

Ministry of Health, 2008. Turkiye Saglik Insangucu Durum Raporu (Report on the Current State of Health Manpower in Turkey). Saglik Bakanligi Yayin No. (Ministry of Health Publication No.) 739, Mart (March).

Nguyen, A., Haile, G. A., 2003. Intergenerational mobility in educational and occupational status: Evidence from the U.S. Lancaster University Management School Working Paper, 2003/043.

OSYM. (2002). 2002 student selection and placement system higher education programs and quotas (2002 Ogrenci Secme ve Yerlestirme Sistemi (OSYS) Yuksekogretim Programlari ve Kontenjanlari Kilavuzu). Ankara: Ogrenci Secme ve Yerlestirme Merkezi (Student Selection and Placement Center).

Ovet, O., 2006. Egitim Fakultesi Ogrencilerinin Ogretmenlik Meslegini Tercih Etmelerinde Etkili Olan Faktorlerin Belirlenmesi (Determination of the factors that influenced the occupational choice of students of education faculty). Master's Thesis. Yeditepe Universitesi, Sosyal Bilimler Enstitusu.

Saks, R. E., \& Shore, S. H. (2005). Risk and career choice. Advances in Economic Analysis and Policy, 5(1) (Article 7)

Tansel, A. (1994). Wage employment, earnings and returns to schooling for men and women in Turkey. Economics of Education Review, 13(4), 305-320.

Tansel, A. (2001). Self-employment, wage-employment, and returns to schooling by gender in Turkey. In S.-I. Djavad (Ed.), Labor and human capital in the middle east: Studies of markets and household behavior. Reading, UK: Ithaca Press.

Tansel, A. (2002). Determinants of school attainment of boys and girls in Turkey: Individual, household and community factors. Economics of Education Review, 21(October (5)), 455-470.

Tansel, A. (2005). Public-private employment choice, wage differentials, and gender in Turkey. Economic Development and Cultural Change, 53(January (2)), 453-477.

Tansel, A., Bircan, F., 2005. Effect of Private Tutoring on University Entrance Examination Performance in Turkey. IZA Discussion Paper No. 1609 (May).

TUIK (Turkish Statistical Institute), 2000. Turkish 2000 Census, 5\% Representative Sample. Ankara, Turkey.

Williams, J. T. (1979). Uncertainty and the accumulation of human capital over the life cycle. The Journal of Business, 52(October (4)), 521-548. 